\title{
Evaluation of Bismuth Modified Carbon Thread Electrode for Simultaneous and Highly Sensitive Cd (II) and Pb (II) Determination
}

\author{
Ayman Ali Saeed, ${ }^{[c]}$ Baljit Singh, ${ }^{[a, b]}$ Mohammed Nooredeen Abbas, ${ }^{[c]}$ and Eithne Dempsey*[a, b]
}

\begin{abstract}
Bismuth film modified and chemically activated carbon micro-thread electrodes were investigated for the simultaneous determination of $\mathrm{Cd}(\mathrm{II})$ and $\mathrm{Pb}(\mathrm{II})$ using square wave anodic stripping voltammetry. The carbon thread electrode was characterised using both surface and electrochemical techniques. Electrochemical impedance spectroscopy (EIS) studies demonstrated that the $\mathrm{H}_{2} \mathrm{SO}_{4} /$ IPA-treated carbon thread electrode showed a much improved resistance response $\left(R_{\mathrm{ct}}=23 \Omega\right)$ compared to the IPA-untreated carbon thread $\left(R_{\mathrm{ct}}=8317 \Omega\right)$. Furthermore, parameters such as the effect of deposition potential, deposition time and $\mathrm{Bi}(\mathrm{III})$ concentration were explored using square wave voltammetry. Detection limits $(\mathrm{S} / \mathrm{N}=$ 3) for $\mathrm{Cd}(\mathrm{II})$ and $\mathrm{Pb}(\mathrm{II})$ were found to be $1.08 \mu \mathrm{gL}^{-1}$ and
\end{abstract}

$0.87 \mu \mathrm{gL}^{-1}$, respectively and response was found to be linear over the range $5-110 \mu \mathrm{gL}^{-1}$. The proposed Bi/IPAtreated carbon thread electrode exhibited a high selectivity towards $\mathrm{Cd}(\mathrm{II})$ and $\mathrm{Pb}$ (II) even in the presence of a range of heavy metals and is capable of repetitive and reproducible measurements, being attributed to the high surface area, geometry and electrode treatment characteristics. The proposed metal ion sensor was employed to determine cadmium and lead in river water samples and $\%$ RSD was found to be $5.46 \%$ and $5.93 \%$ for $\mathrm{Cd}(\mathrm{II})$ and $\mathrm{Pb}(\mathrm{II})$ respectively $(\mathrm{n}=3)$. Such facile sensing components favour the development of cost effective portable devices for environmental sample analysis and electrochemical applications.

Keywords: Square wave anodic stripping voltammetry - Carbon thread - Bismuth electrode • Electrochemical impedance spectroscopy $\cdot \mathrm{Cd}(\mathrm{II}) \cdot \mathrm{Pb}(\mathrm{II})$

\section{Introduction}

Toxic heavy metals form a threat to living organisms due to non-biodegradability and persistence concerns, with even trace level exposure affecting both mankind and aquatic systems $[1,2]$. Lead $(\mathrm{Pb})$ and cadmium $(\mathrm{Cd})$ are very common toxic metal ions, which have been routinely discharged into the environment via electroplating, metallurgical processes, and paper mills $[3,4]$. The world health organisation (WHO) has recommended threshold limit values of $10 \mu \mathrm{g} \mathrm{L}^{-1}$ for $\mathrm{Pb}^{2+}$ and $3 \mu \mathrm{g} \mathrm{L}^{-1}$ for $\mathrm{Cd}^{2+}$ ions in drinking water [5].

Significant efforts have been applied in the quantification of such species at trace level and in monitoring exposure limits. Such techniques include UV-Vis spectrometry [6], colorimetric analysis [7], atomic absorption spectrometry [8], atomic fluorescence spectrometry [9], surface enhanced Raman spectrometry [10], ion chromatography [11], inductively coupled plasma-mass spectrometry (ICPMS) [12] and inductively coupled plasma-optical emission spectrometry (ICP-OES) [13]. However, these methods have some limitations such as; high cost, require complex instrumentation and as such are unsuitable for on-field analysis. Hence, there is a continued effort to realise mobile or portable devices which can provide reliable results at a desired concentration level. Among such analytical techniques, electrochemical methodologies are widely established for heavy metal ion detection [14-16] due to low cost and simplicity, ease of operation, suitability for multiple analysis, and portability for in situ environmental monitoring/field analysis.

Anodic stripping voltammetry is a powerful technique in this regard due to an effective pre-concentration step followed by electrochemical stripping measurements of the accumulated analytes [17]. The selection of a proper electrode material is very important in voltammetry and desired properties for the electrode materials include; high selectivity and sensitivity, reproducibility and longtime stability. In addition, the material should be environmentally friendly, inexpensive, and be capable of mass production. Carbon materials are considered to be good candidates for nano-architectural templates to support

[a] B. Singh, E. Dempsey

Centre for Research in Electroanalytical Technologies (CREATE)

Institute of Technology Tallaght (ITT Dublin), Tallaght, Dublin 24, Ireland

*e-mail: Eithne.Dempsey@ittdublin.ie

[b] B. Singh, E. Dempsey

MiCRA-Biodiagnostics Technology Gateway, CASHSynergy Centre Institute of Technology Tallaght, Dublin 24, Ireland

[c] A. A. Saeed, M. Nooredeen Abbas Electroanalytical Lab., Applied Organic Chemistry Department

National Research Centre, Dokki, Cairo, Egypt 
electrochemically active materials for various applications, because they not only improve the conductivity of such composites but also mitigate instability or cycle degradation related issues $[18,19]$.

In this regard, carbon cloth has been extensively investigated as a conductive substrate, due to cost-effectiveness, reasonable chemical stability, and 3D features. Carbon cloth is also well reported as a material for the fabrication of flexible energy storage devices from design and packaging perspectives [20]. Either untreated or modified activated carbon cloths have been explored as catalysts or supporting matrices in several processes, as electrode materials, and/or as a potential substrates [2126]. Carbon cloth has also been investigated intensively for abatement of gaseous and liquid pollutants [27-29], for separation and purification of biomolecules [30], in gas storage and separation, recovery, purification and sensing of hydrogen $\left(\mathrm{H}_{2}\right)$, and sour gas sweetening [3133]. The main advantages arise from the nano-micro diameter of the fibers [34], faster adsorption kinetics, higher efficiency, and larger capacity for adsorption due to the higher surface area and pore volume [35,36]. Besides, these materials are light and flexible and can be arranged in different stable configurations providing a contiguous carbon form suited for electrical and electrochemical applications [37,38].

Mercury-based electrodes have been mostly used for anodic stripping voltammetry due to their wide cathodic potential window, high hydrogen over potential, good reproducibility, ease of surface renewal and high sensitivity $[39,40]$. However, the toxicity and difficulties associated with storage and disposal restrict its use [41]. Two approaches have been generally utilised to displace mercury in the construction of chemically modified electrodes for trace level determination of heavy metals. One is the use of conductive materials, like bismuth (Bi), antimony ( $\mathrm{Sb}$ ), gold $(\mathrm{Au})$, silver $(\mathrm{Ag})$ film and carbon and boron-doped diamond based materials [42-46]. Another involves the use of receptors including ethylenediamine tetraacetic acid [47], dimethylglyoxime [48], phenanthroline [49], and cysteine [50], which have either electrostatic interactions or complexation capabilities with metal ions and promote pre-concentration of the latter onto the electrode surface.

Recently, bismuth (Bi) film electrodes have attracted considerable interest, possessing behaviour similar to mercury-based electrodes and present remarkably low toxicity [51]. Bismuth offers many advantages over other materials, including simple preparation, low toxicity, well defined and separated stripping signals, wide potential window, high sensitivity, and insensitivity to dissolved oxygen (an essential property for on-site monitoring applications) [51-53]. The superior stripping performances of Bi-based electrodes are well known and attributed to its ability to form fused alloys with other metals, in a similar fashion to mercury [54,55]. However, analysis of heavy metals still remains challenging as these metal ions are normally present at very low levels with complex forms in real samples. On the other hand, in order to perform on-site environmental monitoring of heavy metals at the point of interest, it is important to develop cost effective and portable electrode systems with long-term stability. Therefore, additional efforts are required in order to improve detection at low concentrations and stability for long-time use in environmental analysis.

In this study, we report a simple strategy to fabricate bismuth film modified and chemically activated carbon thread for simultaneous determination of $\mathrm{Cd}(\mathrm{II})$ and $\mathrm{Pb}(\mathrm{II})$ ions using square wave anodic stripping voltammetry. The work employs the use of a single carbon thread which is a unit of the micromesh structure of carbon cloth. The study therefore demonstrates an inexpensive and effective electrode system that is very flexible for use in a range of configurations as well as being suitable for electrochemical determination of heavy metal ions $\left(\mathrm{Cd}^{2+}\right.$ and $\mathrm{Pb}^{2+}$ ).

\section{Experimental}

\subsection{Materials}

Teflon-treated carbon cloth (Clean Fuel Cell Energy, USA). Isopropyl alcohol, potassium hexacyanoferrate(III) (>99\%), potassium hexacyanoferrate(II) trihydrate $(>99.99 \%)$, potassium chloride, sulphuric acid, sodium acetate, cadmium(II) chloride (99.999\%) and bismuth(III) nitrate pentahydrate (98\%) were purchased from Sigma-Aldrich. Lead(II) nitrate (99\%) was purchased from BDH. Acetic acid (99-100\%) was purchased from Riedel-de Haën. Acetate buffer solution was prepared using $0.1 \mathrm{M}$ sodium acetate $\left(\mathrm{C}_{2} \mathrm{H}_{3} \mathrm{NaO}_{2}\right)$ and $0.1 \mathrm{M}$ acetic acid $\left(\mathrm{C}_{2} \mathrm{H}_{4} \mathrm{O}_{2}\right)$.

\subsection{Preparation of the Carbon Thread Electrode}

Prior to electrochemical measurements, the carbon thread was immersed in isopropyl alcohol (IPA) for $5 \mathrm{~min}$, in order to improve the hydrophilicity of the material and to allow water to permeate the micro-pores created during Teflon treatment. The thread was then washed with de-ionised water to remove excess IPA. IPA-treated carbon thread was scanned in $5 \mathrm{~mL}$ of $0.5 \mathrm{M} \mathrm{H}_{2} \mathrm{SO}_{4}$ between $-0.2 \mathrm{~V}$ to $1.6 \mathrm{~V}$ at $100 \mathrm{mV} / \mathrm{s}$ for 25 cycles to activate the carbon thread surface and confirm a reproducible current response. The thread was washed with de-ionised water prior to further electrochemical measurements.

\subsection{Instrumentation and Electrochemical Procedures}

The surface morphology of carbon cloth and carbon thread materials were characterised using scanning electron microscopy (SEM, JEOL JSM-6390LV model). For SEM measurements, a piece of carbon cloth/carbon thread was mounted onto an aluminium sample stub. The electrochemical experiments (cyclic voltammetry, electrochemical impedance spectroscopy and square wave 


\section{Full Paper}

anodic stripping voltammetry) were performed using an electrochemical workstation $\mathrm{CH}$ Instruments Inc. 750A, using $0.5 \mathrm{M} \mathrm{H}_{2} \mathrm{SO}_{4}, 5 \mathrm{mM}\left[\mathrm{Fe}(\mathrm{CN})_{6}\right]^{3-/ 4-}$ and $0.1 \mathrm{M}$ acetate buffer ( $\mathrm{pH} 4.4)$ electrolytes, in a conventional threeelectrode electrochemical cell $(5 \mathrm{~mL})$ at room temperature. A piece of carbon cloth with $1 \mathrm{~cm}$ length, $0.6 \mathrm{~mm}$ width and $0.3 \mathrm{~mm}$ depth, was employed as a working electrode. These dimensions describe the piece of thread taken from the whole carbon cloth but not the actual surface area exposed for deposition of metals - each thread has a large number of sub-threads (filament like structure). Platinum wire and a standard $\mathrm{Ag} / \mathrm{AgCl}$ electrode (filled with $3 \mathrm{M} \mathrm{KCl}$ ) were used as counter and reference electrodes, respectively.

The simultaneous determination of $\mathrm{Cd}^{2+}$ and $\mathrm{Pb}^{2+}$ was carried out using square wave anodic stripping voltammetry (SWASV) in $5 \mathrm{~mL}$ of acetate buffer solution $(0.1 \mathrm{M}$, $\mathrm{pH} 4.4$ ), with known concentrations of $\mathrm{Cd}(\mathrm{II}), \mathrm{Pb}(\mathrm{II})$ and $300 \mu \mathrm{g} \mathrm{L}^{-1} \mathrm{Bi}(\mathrm{III})$ by applying deposition (pre-concentration) and stripping steps. During the pre-concentration step, $-1.1 \mathrm{~V}$ was applied to the carbon thread electrode for 300 seconds in a stirred solution, which resulted in simultaneous deposition of $\mathrm{Bi}(\mathrm{III}), \mathrm{Cd}(\mathrm{II})$ and $\mathrm{Pb}(\mathrm{II})$. Stirring was stopped immediately after the deposition step and following a quiet time of 5 seconds, the electrode was swept anodically using square wave voltammetry $(-1.0 \mathrm{~V}$ to $-0.3 \mathrm{~V}$, amplitude $25 \mathrm{mV}$, frequency $15 \mathrm{~Hz}$ and incremental potential $4 \mathrm{mV}$ ). Following each measurement, the carbon thread electrode was cleaned by holding the potential at $0.3 \mathrm{~V}$ for $120 \mathrm{~s}$ so that the surface was renewed and conditioned for subsequent electrochemical measurements.

\section{Results and Discussion}

\subsection{Surface Characterisation of Carbon Cloth and Carbon Thread Materials}

SEM images have been recorded for a piece of the carbon cloth (Fig. 1a) as well as for a single carbon thread (Fig. 1b). A carbon thread is a single unit of the micromesh structure of the carbon cloth (Fig. 1a) which is composed of large number of such carbon thread units, entangled together to form a complete structure. From the high magnification SEM images, it is evident that even a single carbon thread unit (carbon thread electrode in our case, Fig. 1b-h) consists of large number of entangled carbon sub-threads which has a filament like structure (width approx. $10 \mu \mathrm{m}$ ). This geometrical configuration provides high surface-to-volume ratio and seems ideal for providing sufficient active sites for metal/ion adsorption. Such features make it an ideal substrate for $\mathrm{Bi}(\mathrm{III}), \mathrm{Cd}(\mathrm{II})$ and $\mathrm{Pb}(\mathrm{II})$ adsorption during the pre-concentration step. Successive electrochemical measurements were performed using a single carbon thread as shown in Fig. 1(b-h).

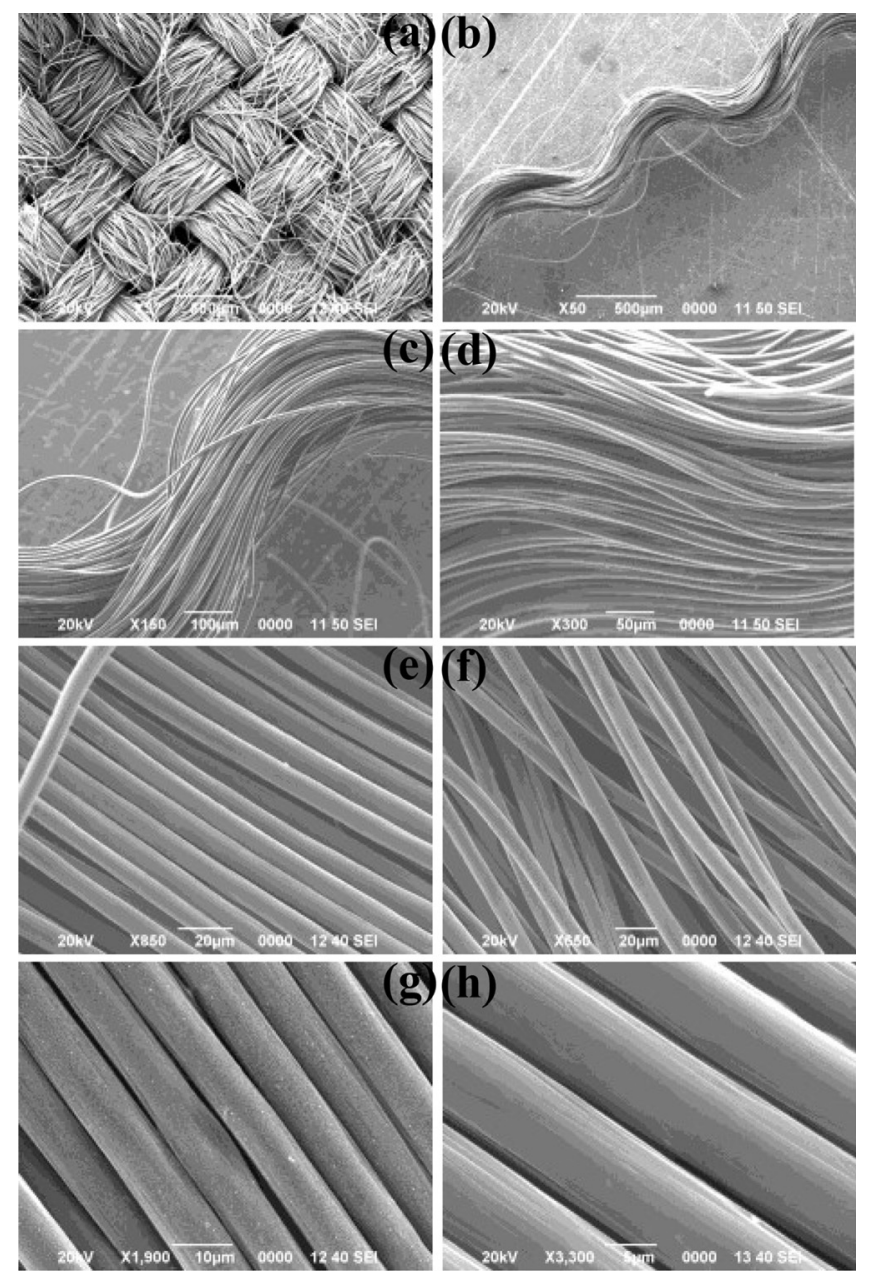

Fig. 1. SEM images of (a) a piece of the carbon cloth and (b-h) single carbon thread unit (which itself is composed of several carbon filaments) of the carbon cloth, at different magnifications (and scale bars); (a) X37 $(500 \mu \mathrm{m})$, (b) X50 $(500 \mu \mathrm{m})$, (c) X150 $(100 \mu \mathrm{m}),(\mathrm{d}) \mathrm{X} 300(50 \mu \mathrm{m}),(\mathrm{e}) \mathrm{X} 850(20 \mu \mathrm{m}),(\mathrm{F}) \mathrm{X} 650(20 \mu \mathrm{m})$ (g) X1900 $(10 \mu \mathrm{m})$ and $(\mathrm{h}) \mathrm{X} 3300(5 \mu \mathrm{m})$.

\subsection{Electrochemical Characterisations of Carbon Thread Electrode}

The electron transfer kinetics characteristics of this electrode was evaluated (using $5 \mathrm{mM}\left[\mathrm{Fe}(\mathrm{CN})_{6}\right]^{3-/ 4-}$ ) via cyclic voltammetry and electrochemical impedance spectroscopy measurements. CVs were recorded for a single carbon thread at different stages of treatment, scanning between $0.7 \mathrm{~V}$ to $-0.2 \mathrm{~V}$ at $100 \mathrm{mV} / \mathrm{s}$. As shown in Fig. 2, the IPA-untreated carbon thread electrode shows a very small oxidation current at $0.55 \mathrm{~V}$ without a detectable reduction peak current, indicating insulator features of the Teflon layer prior to activation, which prevent electronic access of the redox probe to the carbon surface.

Upon immersing the carbon thread in IPA solution for $5 \mathrm{~min}$, clear oxidation and reduction peaks $(\mathrm{E} 1 / 2=$ $214 \mathrm{mV}$ vs. $\mathrm{Ag} / \mathrm{AgCl}$ ) were observed, with $\Delta E=163 \mathrm{mV}$. Further redox improvements were observed upon cycling (25 cycles) IPA-treated carbon thread in $0.5 \mathrm{M} \mathrm{H}_{2} \mathrm{SO}_{4}$ between $-0.2 \mathrm{~V}$ to $1.6 \mathrm{~V}$ at $100 \mathrm{mV} / \mathrm{s}$. This may be attribut- 


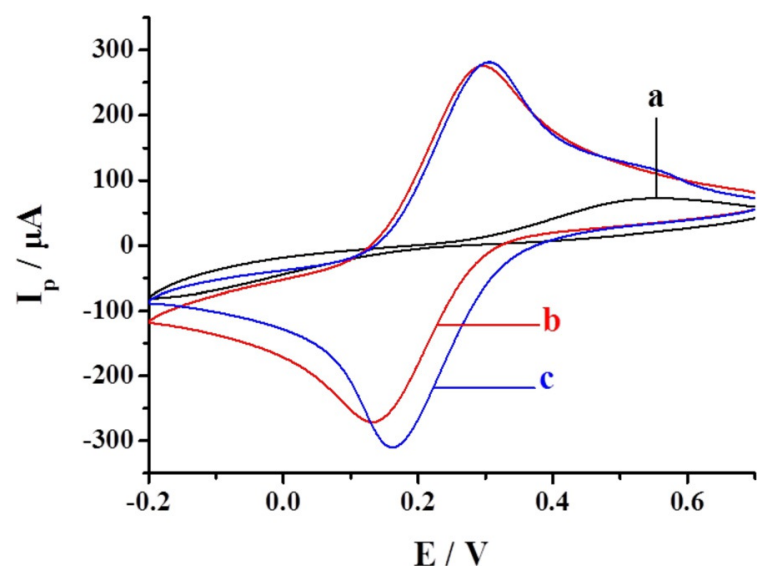

Fig. 2. Cyclic voltammograms of (a) IPA-untreated carbon thread electrode, (b) IPA-treated carbon thread electrode and (c) $\mathrm{H}_{2} \mathrm{SO}_{4} /$ IPA-treated carbon thread electrode, in $5 \mathrm{mM}$ $\left[\mathrm{Fe}(\mathrm{CN})_{6}\right]^{3-/ 4-}$ in $0.1 \mathrm{M} \mathrm{KCl}$ solution.

ed to functionalisation of the carbon thread surface by introduction of e.g. $-\mathrm{OH}$ and $-\mathrm{COOH}-$ groups [56]. Following the activation in $\mathrm{H}_{2} \mathrm{SO}_{4}$, the $\Delta E$ value was further improved to $142 \mathrm{mV}$ with $\left(\mathrm{E}^{1 / 2}=229 \mathrm{mV}\right.$ vs. $\left.\mathrm{Ag} / \mathrm{AgCl}\right)$.

AC impedance experiments (Fig. 3) were performed using the same thread at different stages of electrode
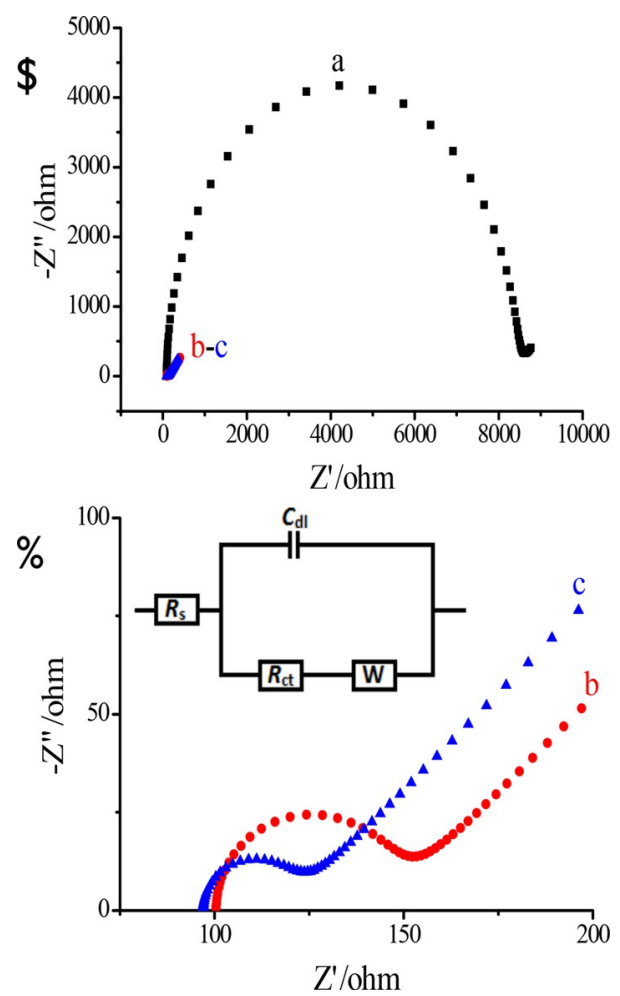

Fig. 3. (A) Nyquist plots of (a) IPA-untreated carbon thread, (b) IPA-treated carbon thread and (c) $\mathrm{H}_{2} \mathrm{SO}_{4}$ /IPA-treated carbon thread in $5 \mathrm{mM}\left[\mathrm{Fe}(\mathrm{CN})_{6}\right]^{3-14-}$ solution (initial potential $0.22 \mathrm{~V}$, frequency range $0.1 \mathrm{~Hz}$ to $10^{5} \mathrm{~Hz}$ ). (B) Enlarged view for $\mathrm{b}$ and c in Fig. 3 (A). Equivalent circuit used for $R_{\mathrm{ct}}$ calculations is shown as inset. modification in $5 \mathrm{mM}\left[\mathrm{Fe}(\mathrm{CN})_{6}\right]^{3-/ 4-}$ at $0.22 \mathrm{~V}$ and frequency range from $0.1 \mathrm{~Hz}$ to $10^{5 \mathrm{~Hz}}$. The resultant Nyquist plot shows a semicircle portion at higher frequencies corresponding to the electron transfer-limited process and a linear part at the lower frequency range representing the diffusion limited process. The semicircle diameter in the Nyquist plot is a measure of the charge transfer-resistance $\left(R_{\mathrm{ct}}\right)$ and is directly related to the electron-transfer process of the redox couple at the interface. The obtained data was fitted by applying an equivalent circuit for the system to achieve $R_{\mathrm{ct}}$ values. The results of impedance were in agreement with the cyclic voltammetry studies. Overall impedance experiments shows that the IPA-untreated carbon thread exhibited very high resistance $\left(R_{\mathrm{ct}}=8317 \Omega\right)$ which again confirms the sluggish kinetic nature of the untreated surface. Once the electrode was immersed in IPA the insulating organic layer is removed and the underlying carbon thread surface becomes electrochemically active with the charge transfer process being accompanied with a large decrease (approx. 180 times) in the resistance $\left(R_{\mathrm{ct}}=46 \Omega\right)$. This confirms the importance of the IPA treatment as it results in significant response improvements. Furthermore, upon cycling the IPA-treated thread in $\mathrm{H}_{2} \mathrm{SO}_{4}$ for 25 cycles, the carbon thread electrode showed even better response characteristics $\left(R_{\mathrm{ct}}=23 \Omega\right)$. This could be attributed to the electrode surface functionalisation which enhances the electron transfer process and again confirms surface activation. Overall, the IPA and acid treatments resulted in redox characteristics improvement of the electrode and contributed hugely to the electrode response. From now onwards the IPA and acid $\left(\mathrm{H}_{2} \mathrm{SO}_{4}\right)$ treated (or activated) thread electrode is labelled as IPA-treated carbon thread electrode.

\subsection{Electrochemical Response Optimisations of Carbon Thread Electrode}

The influence of the various stages of electrode pre-treatment was investigated in the presence of $\mathrm{Cd}(\mathrm{II})$ and $\mathrm{Pb}(\mathrm{II}), 50 \mu \mathrm{gL}^{-1}$. The pre-concentration step was performed in acetate buffer solution at $-1.1 \mathrm{~V}$ for $120 \mathrm{~s}$ and the stripping potential window was from $-1.0 \mathrm{~V}$ to $-0.2 \mathrm{~V}$. In the presence of $300 \mu \mathrm{gL}^{-1} \mathrm{Bi}$ (III), the IPA-untreated carbon thread (carbon thread without IPA treatment - Bi/IPA-untreated carbon thread) showed a small response for $\mathrm{Pb}(\mathrm{II})$ and almost negligible response for $\mathrm{Cd}(\mathrm{II})$ - as shown in Fig. 4a. This confirms that the Teflon layer prevents the deposition of the metals even in the presence of Bi(III) (Fig. 4a). The IPA-treated surface resulted in $\mathrm{Pb}(\mathrm{II})$ deposition during the pre-concentration step, however there was no significant increment in the current response for the cadmium region (Fig. 4b). The combination of both IPA treatment and addition of $300 \mu \mathrm{gL}^{-1} \mathrm{Bi}(\mathrm{III})$, allowed $\mathrm{Cd}(\mathrm{II})$ to deposit during the pre-concentration step $(-1.1 \mathrm{~V})$ - bismuth forms alloys with cadmium hence facilitating its deposition (Fig. 4c). 


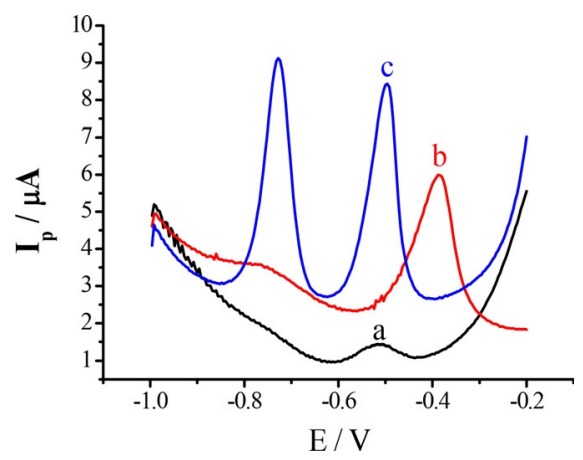

Fig. 4. SWASV of $50 \mu \mathrm{gL}^{-1} \mathrm{Cd}(\mathrm{II})$ and $\mathrm{Pb}$ (II) at $-1.1 \mathrm{~V}$ for $120 \mathrm{~s}$ (a) Bi/IPA-untreated carbon thread electrode, (b) IPAtreated carbon thread electrode and (c) Bi/IPA-treated carbon thread electrode.

This indicates that cadmium cannot be deposited in the absence of $\mathrm{Bi}(\mathrm{III})$ though it was possible to detect $\mathrm{Pb}(\mathrm{II})$. However, the presence of $\mathrm{Bi}$ (III) improves the $\mathrm{Pb}$ (II) signal and both the addition of $\mathrm{Bi}$ and IPA treatment were employed for further investigations. The proposed electrode is labelled as Bi/IPA-treated carbon thread electrode. Furthermore the performance of the treated carbon thread electrode toward $\mathrm{Cd}(\mathrm{II})$ and $\mathrm{Pb}$ (II) ions was investigated by considering the parameters of the SWASV analysis.

Optimisation of the experimental conditions could increase the deposition of the metal ions during the preconcentration step with subsequent increase in signal during the stripping step. The effect of deposition potential, deposition time and $\mathrm{Bi}(\mathrm{III})$ concentration were examined and discussed below.

\subsubsection{Effect of Deposition Potential}

The effect of the deposition potential on the stripping current signals of $\mathrm{Cd}(\mathrm{II})$ and $\mathrm{Pb}(\mathrm{II})$ is shown in Fig. 5 (deposition time $120 \mathrm{~s}$ ). The current signals of both metal ions exhibited a clear dependence on the deposition potential of the pre-concentration step. By shifting the dep-

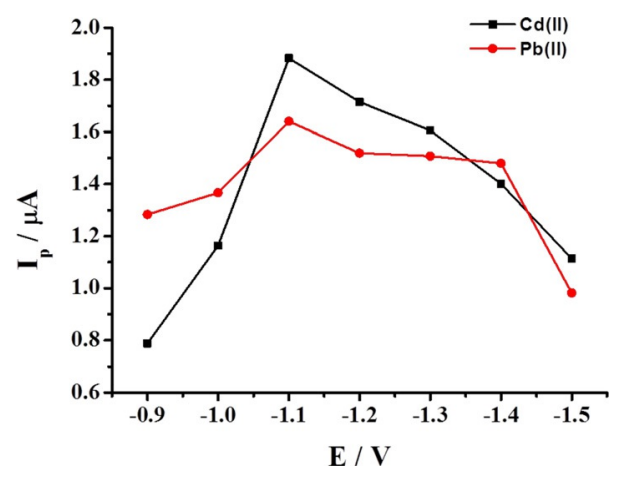

Fig. 5. The effect of deposition potential on the SWASV of $30 \mu \mathrm{g} \mathrm{L}^{-1} \mathrm{Cd}(\mathrm{II})$ and $\mathrm{Pb}(\mathrm{II})$ at Bi/IPA-treated carbon thread electrode. Deposition time $120 \mathrm{~s}$. osition potential cathodically from $-0.9 \mathrm{~V}$ to $-1.1 \mathrm{~V}$, the signals of $\mathrm{Cd}(\mathrm{II})$ and $\mathrm{Pb}(\mathrm{II})$ were improved significantly. Further cathodic shift in the potential $>-1.1 \mathrm{~V}$ was accompanied by a decrease in the current signals for both metals, as hydrogen evolution became more obvious at these high negative potentials, influencing the metal alloy formation. Therefore, a deposition potential of $-1.1 \mathrm{~V}$ was chosen as the optimum potential for $\mathrm{Cd}(\mathrm{II})$ and $\mathrm{Pb}$ (II) separation and quantitation.

\subsection{2-Effect of Deposition Time}

The influence of the deposition time on the stripping current signals of $\mathrm{Cd}(\mathrm{II})$ and $\mathrm{Pb}$ (II) was examined (over the range of $60-600 \mathrm{~s}$ ) and results are shown in Fig. 6. The stripping current values increased as expected by prolonging the deposition time with a linear dependence. The signals did not plateau which could be attributed to the high surface area of carbon thread electrode. In order to minimise time to result while retaining analytical performance, deposition time of $120 \mathrm{~s}$ and $300 \mathrm{~s}$ were chosen for the SWASV experiments for $\mathrm{Cd}(\mathrm{II})$ and $\mathrm{Pb}(\mathrm{II})$.

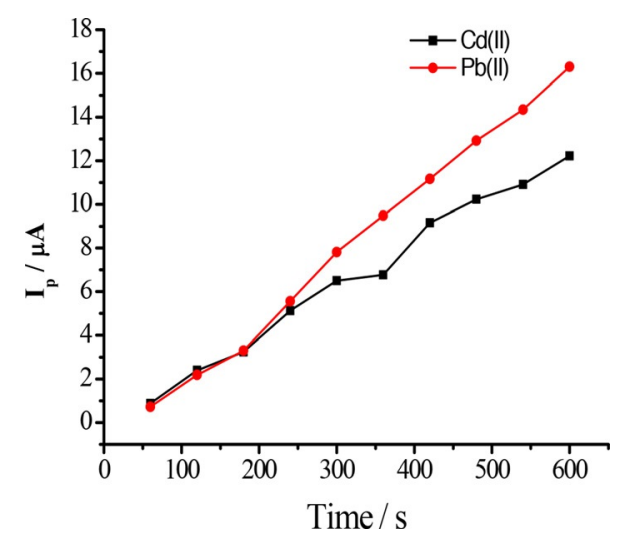

Fig. 6. The effect of deposition time on the SWASV of $30 \mu \mathrm{g} \mathrm{L}{ }^{-1} \mathrm{Cd}(\mathrm{II})$ and $\mathrm{Pb}(\mathrm{II})$ at $\mathrm{Bi} / \mathrm{IPA}$-treated carbon thread electrode.

\subsubsection{Effect of Bi(III) Concentration}

The effect of $\mathrm{Bi}(\mathrm{III})$ concentration on the SWASV of $\mathrm{Cd}(\mathrm{II})$ and $\mathrm{Pb}(\mathrm{II}), 30 \mu \mathrm{g} \mathrm{L}^{-1}$ each, was examined over the range $100-600 \mu \mathrm{gL}^{-1} \mathrm{Bi}(\mathrm{III})$ at a deposition potential of $-1.1 \mathrm{~V}$ and a deposition time of $120 \mathrm{~s}$. Fig. 7 shows the response behaviour and dependence of the current response of $\mathrm{Cd}(\mathrm{II})$ and $\mathrm{Pb}(\mathrm{II})$ ions on the bismuth film thickness. The peak current of both metal ions increased as the $\mathrm{Bi}(\mathrm{III})$ concentration increased from 100 to $300 \mu \mathrm{gL}^{-1}$. Any further $\mathrm{Bi}(\mathrm{III})$ addition $\left(>300 \mu \mathrm{gL}^{-1}\right)$ resulted in a decrease in the SWV current of the metal ions, possibly due to film thickness effects. Therefore, the optimised $\mathrm{Bi}(\mathrm{III})$ concentration was chosen to be $300 \mu \mathrm{g} \mathrm{L} \mathrm{L}^{-1}$ for the simultaneous determination of $\mathrm{Cd}(\mathrm{II})$ and $\mathrm{Pb}(\mathrm{II})$. 


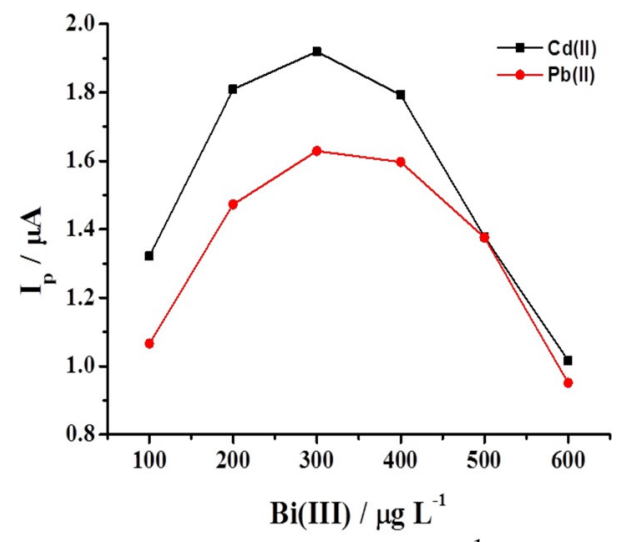

Fig. 7. The effect of $\mathrm{Bi}(\mathrm{III})$ on the SWASV of $\mathrm{Cd}(\mathrm{II})$ and $\mathrm{Pb}(\mathrm{II}), 30 \mu \mathrm{g} \mathrm{L}^{-1}$ each, for $120 \mathrm{~s}$ at $-1.1 \mathrm{~V}$ at $\mathrm{Bi} / \mathrm{IPA}$-treated carbon thread electrode.

\subsection{Analytical Performance of Bi/IPA-treated Carbon Thread Electrode}

The SWASV response of Bi/IPA-treated carbon thread electrode towards $\mathrm{Cd}(\mathrm{II})$ and $\mathrm{Pb}$ (II) was examined by increasing the metal ion concentrations under optimal experimental parameters as discussed above. Calibration curves for the simultaneous determination of $\mathrm{Cd}(\mathrm{II})$ and $\mathrm{Pb}$ (II) at $\mathrm{Bi} / \mathrm{IPA}$-treated carbon thread electrode are shown in Fig. 8. The calibration curves were linear over the range from $5-110 \mu \mathrm{LL}^{-1}$ with $\mathrm{y}=0.6298 \mathrm{x}-6.6021$ and coefficient of determination equals 0.9896 for $\mathrm{Cd}(\mathrm{II})$ and $\mathrm{y}=0.474 \mathrm{x}-4.0547$ with a coefficient of determination equals 0.9915 for $\mathrm{Pb}(\mathrm{II})$. The detection limits for $\mathrm{Cd}(\mathrm{II})$ and $\mathrm{Pb}(\mathrm{II})$ were calculated to be 1.08 and $0.87 \mu \mathrm{gL}^{-1}$, respectively, based on $3 \sigma$ with $300 \mathrm{~s}$ deposition time. It is expected that with prolonged deposition time, lower detection limits for both metal ions could be achieved. The analytical performance of the proposed sensor (Bi/IPAtreated carbon thread electrode) was compared with other reported $\mathrm{Bi}$ film based electrodes and results are summarised in Table 1. From the comparison, it can be seen that the proposed electrochemical sensor exhibited low detection limit and broad linear range, which could be attributed to the high surface area, geometry and electrode treatment characteristics of the carbon thread
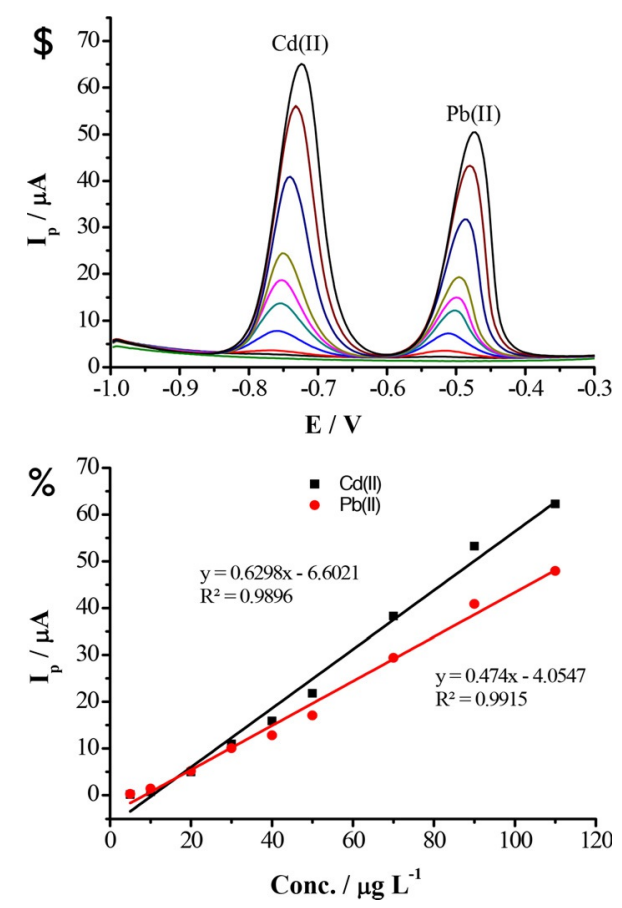

Fig. 8. (A) SWASV response at Bi/IPA-treated carbon thread electrode in $0.1 \mathrm{M}$ acetate buffer solution ( $\mathrm{pH} 4.4)$ containing different concentrations of $\mathrm{Cd}(\mathrm{II})$ and $\mathrm{Pb}(\mathrm{II})$. (B) Calibration curve for the stripping peak current as a function of $\mathrm{Cd}(\mathrm{II})$ and $\mathrm{Pb}(\mathrm{II})$ concentrations.

which collectively influence the deposition of metal ions in an efficient way.

\subsection{Repeatability and Reproducibility}

In order to test the repeatability of the results, IPA-treated electrodes were used to measure $30 \mu \mathrm{g} \mathrm{L}^{-1} \mathrm{Cd}(\mathrm{II})$ and $\mathrm{Pb}(\mathrm{II})$ in acetate buffer solution $(0.1 \mathrm{M}, \mathrm{pH} 4.4)$ containing $300 \mu \mathrm{g} \mathrm{L}^{-1}$ of $\mathrm{Bi}(\mathrm{III})$. The experiment was repeated 5 times using the same carbon thread electrode. Relative standard deviation ( $\% \mathrm{RSD}, \mathrm{n}=5$ ) of $11.8 \%$ for $\mathrm{Cd}(\mathrm{II})$ and $6.8 \%$ for $\mathrm{Pb}(\mathrm{II})$ were found. The reproducibility of the results was tested using 8 different carbon threads under similar fabrication and operating conditions. The relative standard deviation (\% RSD) of the obtained re-

Table 1. Comparison of analytical performance (in terms of linear range and limit of detection) of the proposed sensor (Bi/IPA-treated carbon thread electrode) vs. reported Bi film-based electrodes.

\begin{tabular}{|c|c|c|c|c|c|c|}
\hline \multirow[t]{2}{*}{ Electrode material } & \multirow[t]{2}{*}{ Time (s) } & \multicolumn{2}{|c|}{$L R\left(\mu g \mathrm{~L}^{-1}\right)$} & \multicolumn{2}{|c|}{$L O D\left(\mu \mathrm{g} \mathrm{L}^{-1}\right)$} & \multirow[t]{2}{*}{ Ref. } \\
\hline & & $\mathrm{Cd}(\mathrm{II})$ & $\mathrm{Pb}(\mathrm{II})$ & $\mathrm{Cd}(\mathrm{II})$ & $\mathrm{Pb}(\mathrm{II})$ & \\
\hline $\mathrm{RGO} / \mathrm{Bi} / \mathrm{CPE}$ & 400 & $20-120$ & $20-120$ & 2.8 & 0.55 & 57 \\
\hline Bi-CNT/SPE & 300 & $2-100$ & $2-100$ & 0.7 & 1.3 & 58 \\
\hline MMT/BiCE & 120 & $1-24$ & $1-24$ & 0.35 & 0.2 & 59 \\
\hline $\mathrm{SPE}-\mathrm{Bi}_{2} \mathrm{O}_{3}$ paste on $\mathrm{GC}$ paste & 300 & $20-100$ & $20-100$ & 1.5 & 2.3 & 60 \\
\hline $\mathrm{Bi} / \mathrm{CPE}$ & 300 & 10-100 & 10-100 & 1.2 & 0.9 & 61 \\
\hline $\mathrm{Bi}_{2} \mathrm{O}_{3} / \mathrm{SPE}$ & 120 & $20-300$ & $20-300$ & 8.0 & 16.0 & 62 \\
\hline $\mathrm{Bi} / \mathrm{Au}-\mathrm{GN}-\mathrm{Cys} / \mathrm{GCE}$ & 800 & $0.5-40$ & $0.5-40$ & 0.1 & 0.05 & 63 \\
\hline Bi/IPA-treated CC & 300 & $5-110$ & $5-110$ & 1.08 & 0.87 & This work \\
\hline
\end{tabular}


sults was calculated to be $13.4 \%$ for $\mathrm{Cd}(\mathrm{II})$ and $13.1 \%$ for $\mathrm{Pb}(\mathrm{II})$. The greater variation between carbon threads is attributed to differences in number of filaments (subunits thread) with altered electroactive area.

\subsection{Interference Studies}

Bismuth can form alloys with most metal ions which may also be deposited at this potential, therefore it is important to test the effect of such metal ion interferents on the response peak of $\mathrm{Cd}(\mathrm{II})$ and $\mathrm{Pb}(\mathrm{II})$. Here, current signals were recorded firstly following deposition of $\mathrm{Cd}(\mathrm{II})$ and $\mathrm{Pb}(\mathrm{II}), 50 \mu \mathrm{g} \mathrm{L}^{-1}$ each, in $5 \mathrm{~mL}$ acetate buffer solution (0.1 M, pH 4.4) containing $300 \mu \mathrm{gL}^{-1} \mathrm{Bi}(\mathrm{III})$ at $-1.1 \mathrm{~V}$ for $120 \mathrm{~s}$. Then, 10 -fold $\left(500 \mu \mathrm{g} \mathrm{L}^{-1}\right)$ of each interfering metal ion was added to the cell solution and the experiment was repeated. The current values were compared before and after introducing the tested metal ion and based on data in Table 2, the majority of the interfering metal ions did not exhibit a significant decrease in the original peak current except in the case of $\mathrm{Ni}(\mathrm{II})$ which decreased the $\mathrm{Cd}(\mathrm{II})$ by $27.67 \%$ and $\mathrm{Pb}(\mathrm{II})$ by $22.68 \%$.

Overall, the Bi/IPA-treated carbon thread electrode has a high selectivity towards $\mathrm{Cd}(\mathrm{II})$ and $\mathrm{Pb}(\mathrm{II})$ even in the presence of a wide range of heavy metals. However, the interference caused by 10 -fold $\mathrm{Cu}^{2+}$ is relatively higher $(\approx 50 \%$ decrease in response) for $\mathrm{Cd}(\mathrm{II})$ and $\mathrm{Pb}$ (II) signals. This interference is attributed to the formation of inter-metallic compounds during the deposition step as previously reported [64].

In order to test the effect of $\mathrm{Cd}(\mathrm{II})$ on $\mathrm{Pb}(\mathrm{II})$ and vice versa during their simultaneous determination, $50 \mu \mathrm{gL}^{-1}$ of one metal kept constant while the concentration of the

Table 2. Interference study.

\begin{tabular}{lrr}
\hline Interferences & \multicolumn{2}{c}{ Contribution $(\%)$} \\
\cline { 2 - 3 } & $\mathrm{Cd}(\mathrm{II})$ & $\mathrm{Pb}(\mathrm{II})$ \\
\hline $\mathrm{K}^{+}$ & 7.76 & 2.99 \\
$\mathrm{Li}^{+}$ & 2.32 & 7.88 \\
$\mathrm{Mg}^{2+}$ & -8.74 & -1.59 \\
$\mathrm{Cr}^{3+}$ & 2.17 & 7.08 \\
$\mathrm{Mn}^{2+}$ & 1.39 & 11.96 \\
$\mathrm{Fe}^{2+}$ & 1.41 & 10.94 \\
$\mathrm{Co}^{2+}$ & -4.06 & 8.73 \\
$\mathrm{Ni}^{2+}$ & -27.67 & -22.68 \\
$\mathrm{Zn}^{2+}$ & -8.70 & -4.88 \\
\hline
\end{tabular}
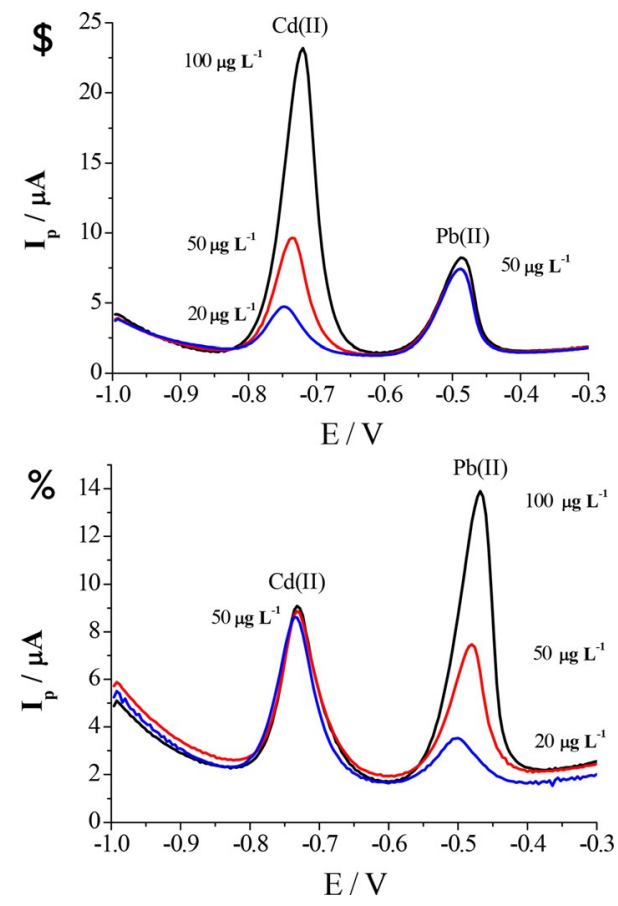

Fig. 9. SWASV response at Bi/IPA-treated carbon thread electrode in $0.1 \mathrm{M}$ acetate buffer solution ( $\mathrm{pH} 4.4$ ) containing (A) $50 \mu \mathrm{L} \mathrm{L}^{-1} \mathrm{~Pb}$ (II) and different concentrations of $\mathrm{Cd}(\mathrm{II})$ and (B) $50 \mu \mathrm{gL}^{-1} \mathrm{Cd}(\mathrm{II})$ and different concentrations of $\mathrm{Pb}(\mathrm{II})$. Deposition time $120 \mathrm{~s}$.

other was altered $\left(20,50\right.$ and $\left.100 \mu \mathrm{gL}^{-1}\right)$. As shown in Fig. 9, the signal alteration was insignificant indicating the sensor's ability to determine both metals simultaneously.

\subsection{Real Sample Analysis}

In order to evaluate the accuracy and efficiency of the proposed sensor in practical environments, Bi/IPA-treated carbon thread electrode was employed to determine $\mathrm{Cd}(\mathrm{II})$ and $\mathrm{Pb}$ (II) in river water samples (Table 3 ). The samples were collected from Whitestown stream located in Sean Walsh Park (Tallaght, Dublin, Ireland). $2.5 \mathrm{~mL}$ of the river sample was diluted by addition of $2.5 \mathrm{~mL}$ of $0.1 \mathrm{M}$ acetate buffer solution ( $\mathrm{pH} 4.4$ ) and $300 \mu \mathrm{gL}^{-1}$ of $\mathrm{Bi}(\mathrm{III})$ was added to the solution mixture. The measurement was repeated 3 times and no obvious peaks were observed for both metals.

Table 3. Determination of $\mathrm{Cd}(\mathrm{II})$ and $\mathrm{Pb}(\mathrm{II})$ in river water samples.

\begin{tabular}{|c|c|c|c|c|c|c|c|c|}
\hline \multirow[t]{2}{*}{ Sample } & \multicolumn{2}{|c|}{ Added } & \multicolumn{2}{|c|}{ Found } & \multicolumn{2}{|l|}{ RSD } & \multicolumn{2}{|c|}{ Recovery } \\
\hline & \multicolumn{2}{|c|}{$\left(\mu \mathrm{gL}^{-1}\right)$} & \multicolumn{2}{|c|}{$\left(\mu \mathrm{gL}^{-1}\right)$} & \multicolumn{2}{|c|}{$(\%, \mathrm{n}=3)$} & \multicolumn{2}{|c|}{$(\%, n=3)$} \\
\hline River water & $\mathrm{Cd}^{2+}$ & $\mathbf{P b}^{2+}$ & $\mathrm{Cd}^{2+}$ & $\mathbf{P b}^{2+}$ & $\mathrm{Cd}^{2+}$ & $\mathbf{P b}^{2+}$ & $\mathrm{Cd}^{2+}$ & $\mathbf{P b}^{2+}$ \\
\hline & 0 & 0 & * & * & - & - & - & - \\
\hline & 10 & 10 & 10.63 & 8.90 & 5.46 & 5.93 & 106.3 & 89 \\
\hline & 20 & 20 & 19.06 & 19.37 & 7.35 & 2.24 & 95.3 & 96.9 \\
\hline
\end{tabular}

* Below detection limit 
$2.5 \mathrm{~mL}$ of the collected sample was added to $2.5 \mathrm{~mL}$ of $20 \mu \mathrm{gL}^{-1}$ of $\mathrm{Cd}(\mathrm{II})$ and $20 \mu \mathrm{gL}^{-1}$ of $\mathrm{Pb}(\mathrm{II})$ prepared in acetate buffer solution and finally $\mathrm{Bi}$ (III) was added. The response standard deviation (SD) for three measurements was found to be 0.005 and $0.015 \mu \mathrm{g} \mathrm{L}^{-1}$ for $\mathrm{Cd}(\mathrm{II})$ and $\mathrm{Pb}(\mathrm{II})$, respectively. In an another experiment, $40 \mu \mathrm{g} \mathrm{L}^{-1}$ of $\mathrm{Cd}(\mathrm{II})$ and $40 \mu \mathrm{gL}^{-1}$ of $\mathrm{Pb}$ (II) prepared in acetate buffer solution was added to $2.5 \mathrm{~mL}$ of the collected sample with the addition of $\mathrm{Bi}(\mathrm{III})$. The standard deviation for the three measurements was found to be 0.39 and $0.11 \mu \mathrm{g} \mathrm{L}^{-1}$ for $\mathrm{Cd}(\mathrm{II})$ and $\mathrm{Pb}(\mathrm{II})$ respectively.

\section{Conclusions}

The proposed Bi/IPA-treated carbon thread electrode exhibited high selectivity towards $\mathrm{Cd}(\mathrm{II})$ and $\mathrm{Pb}$ (II) even in the presence of a range of heavy metals and is capable of repetitive and reproducible measurements. This was attributed to the high surface area, geometry and electrode treatment characteristics of the carbon thread. Overall, the bismuth film modification and IPA/acid treatments resulted in characteristics (surface area, electron transfer processes and electrode response) improvement of the carbon thread electrode. The work highlights the efficient utilisation of a single thread of a carbon cloth material and demonstrated a novel and inexpensive electrode system capable of heavy metal ion determination. Evaluation of such facile and portable devices in continuous mode on-site will be the subject of further work via integrated microfluidic elements with extensive validation and testing. Overall activated carbon thread is a promising new sensor material and capable of promoting a new conception in equipment design/arrays, favouring the development of novel and cost effective portable devices for environmental samples analysis and electrochemical applications.

\section{Acknowledgements}

Authors thank and acknowledge EU for supporting this work through FP7 Marie Curie IRSES Project: Micro/ nano sensors for early cancer warning system - diagnostic and prognostic information "SMARTCANCERSENS".

\section{References}

[1] J. O. Nriagu, J. M. Pacyna, Nature 1988, 333, 134.

[2] M. A. El Mhammedi, M. Achak, A. Chtaini, J. Hazard. Mater. 2009, 161, 55.

[3] I. Cesarino, É. T. G. Cavalheiro, C. M. A. Brett, Electroanalysis 2010, 22, 61.

[4] L. T. Viyannalage, S. Bliznakov, N. Dimitrov, Anal. Chem. 2008, 80, 2042.

[5] WHO Library Cataloguing-in-Publication Data, World Health Organisation, Guidelines for drinking-water quality [electronic resource]: incorporating first addendum. Vol. 1, $3^{\text {rd }}$ edition, ISBN 9241546964 (NLM classification: WA 675).
[6] J. P. Cornard, A. Caudron, J. C. Merlin, Polyhedron 2006, $25,2215$.

[7] Y. Zhou, S. Wang, K. Zhang, X. Jiang, Angew. Chem. Int. Ed. 2008, 47, 7454.

[8] H. Bagheri, A. Afkhami, M. Saber-Tehrani, H. Khoshsafar, Talanta 2012, 97, 87.

[9] J. L. Guzmán-Mar, L. Hinojosa-Reyes, A. M. Serra, A. Hernández-Ramírez, V. Cerdá, Anal. Chim. Acta 2011, 708, 11.

[10] Y. Ma, H. Liu, K. Qian, L. Yang, J. Liu, J. Colloid Inter. Sci. 2012, 386, 451.

[11] W. Zeng, Y. Chen, H. Cui, F. Wu, Y. Zhu, J. S. Fritz, J. Chromatogr. A 2006, 1118, 68 .

[12] S. Arpadjan, G. Celix, S. Taskesen, S. Gucer, Food Chem. Toxicol. 2008, 46, 2871.

[13] L. Zhao, S. Zhong, K. Fang, Z. Qian, J. Chen, J. Hazard. Mater. 2012, 206, 239.

[14] M. N. Abbas, E. Zahran, J. Electroanal. Chem. 2005, 576, 205.

[15] M. N. Abbas, G. A. E. Mostafa, Anal. Chim. Acta 2003, 478, 329.

[16] S. S. M. Hassan, M. N. Abbas, G. A. E. Moustafa, Talanta 1996, 43, 797.

[17] J. Wang, Analytical Electrochemistry, $3^{\text {rd }}$ edition, Wiley, Hoboken, New Jersey, 2006.

[18] Y. G. Wang, H. Q. Li, Y. Y. Xia, Adv. Mater. 2006, 18, 2619.

[19] D. Zhang, X. Zhang, Y. Chen, P. Yu, C. Wang, Y. Ma, J. Power Sources 2011, 196, 5990.

[20] Y. Y. Horng, Y. C. Lu, Y. K. Hsu, C. C. Chen, L. C. Chen, K. H. Chen, J. Power Sources 2010, 195, 4418.

[21] Y. Matatov-Meytal, M. Sheintuch, Appl. Catal. A 2002, 231, 1.

[22] U. Matatov-Meytal, M. Sheintuch, Catal. Today 2005, 102103,121

[23] A. Perrard, P. Gallezot, J. P. Joly, R. Durand, C. Baljou, B. Coq, P. Trens, Appl. Catal. A 2007, 331, 100.

[24] I. Isaev, G. Salitra, A. Soffer, Y. S. Cohen, D. Aurbach, J. Fischer, J. Power Sources 2003, 119-121, 28.

[25] H. Xia, Advanced Materials Research 2012, 347-353, 1869.

[26] M. Zhong, Y. Song, Y. Li, C. Ma, X. Zhai, J. Shi, Q. Guo, L. Liu, J. Power Sources 2012, 217, 6.

[27] J. H. Tsai, H. M. Chiang, G. Y. Huang, H. L. Chiang, J. Hazard. Mater. 2008, 154, 1183.

[28] R. Chand, R. Molina, I. Johnson, A. Hans, D. H. Bremner, Water Science and Technology 2010, 61, 2817.

[29] A. Hajian, S. Azizian, J. Dispersion Science and Technology 2012, 33, 1629.

[30] W. Shen, H. Wang, R. Guan, Z. Li, Colloids and Surfaces A 2008, 331, 263.

[31] P. J. M. Carrott, J. M. V. Nabais, M. M. L. R. Carrott, J. A. Menendez, Carbon 2004, 42, 227.

[32] J. Zhang, W. Luan, H. Huang, Y. Qi, S. T. Tu, Sens. Actuat. B 2007, 128, 266.

[33] L. Zubizarreta, A. Arenillas, J. J. Pis, Inter. J. Hydrogen Energy 2009, 34, 4575.

[34] S. Y. Lee, S. J. Park, J. Colloid Inter. Sci. 2013, 389, 230.

[35] W. Lu, D. D. L. Chung, Carbon 2001, 39, 39.

[36] X. Ma, H. Yang, L. Yu, Y. Chen, Y. Li, Materials 2014, 7, 4431.

[37] C. O. Ania, F. Beguin, Environ. Sci. Technol. 2008, 42, 4500.

[38] G. Milczarek, A. Ciszewski, I. Stepniak, J. Power Sources 2011, 196, 7882.

[39] K. Seo, S. Kim, J. Park, Anal. Chem. 1998, 70, 2936.

[40] H. P. Wu, Anal. Chem. 1994, 66, 3151.

[41] R. Ouyang, Z. Zhu, C. E. Tatum, J. Q. Chambers, Z. L. Xue, J. Electroanal. Chem. 2011, 656, 78. 
[42] K. C. Armstrong, C. E. Tatum, R. N. Dansby-Sparks, J. Q. Chambers, Z. L. Xue, Talanta 2010, 82, 675.

[43] Y. Bonfil, M. Brand, E. K. Eisner, Anal. Chim. Acta 2002, 464, 99.

[44] V. Guzsvány, H. Nakajima, N. Soh, K. Nakano, T. Imato, Anal. Chim. Acta 2010, 658, 12.

[45] O. Estévez-Hernández, I. Naranjo-Rodríguez, J. L. HidalgoHidalgo de Cisneros, E. Reguera, Sens. Actuat. B 2007, 123, 488.

[46] A. Manivannan, R. Kawasaki, D. A. Tryk, A. Fujishima, Electrochim. Acta 2004, 49, 3313.

[47] M. Heitzmann, C. Bucher, J. C. Moutet, E. Pereira, B. L. Rivas, G. Royal, E. Saint-Aman, Electrochim. Acta 2007, 52, 3082.

[48] Z. Zhang, H. Liu, H. Zhang, Y. Li, Anal. Chim. Acta 1996, $333,119$.

[49] S. V. Prabhu, R. P. Baldwin, L. Kryger, Anal. Chem. 1987, 59, 1074.

[50] W. Yang, J. J. Gooding, D. B. Hibbert, J. Electroanal. Chem. 2001, 516, 10.

[51] E. A. Hutton, S. B. Hočevar, L. Mauko, B. Ogorevc, Anal. Chim. Acta 2006, 580, 244.

[52] J. Wang, Electroanalysis 2005, 17, 1341.

[53] G. Aragay, J. Pons, A. Merkoci, Chemical Reviews 2011, $111,3433$.
[54] J. Wang, J. Lu, U. A. Kirgoz, S. B. Hočevar, B. Ogorevc, Anal. Chim. Acta 2001, 434, 29.

[55] E. Fischer, C. M. G. van den Berg, Anal. Chim. Acta 1999, 385, 273.

[56] D. Rathod, S. Warren, K. Keane, D. A. Egan, E. Dempsey, Anal. Methods 2011, 3, 799.

[57] P. K. Sahoo, B. Panigrahy, S. Sahoo, A. K. Satpati, D. Li, D. Bahadur, Biosens. Bioelectron. 2013, 43, 293.

[58] G. H. Hwang, W. K. Han, J. S. Park, S. G. Kang, Talanta 2008, 76, 301.

[59] L. Luo, X. Wang, Y. Ding, Q. Li, J. Jia, D. Deng, Appl. Clay Sci. 2010, 50, 154.

[60] G. H. Hwang, W. K. Han, J. S. Park, S. G. Kang, Sens. Actuat. B 2008, 135, 309.

[61] S. B. Hočevar, I. Švancara, K. Vytřas, B. Ogorevc, Electrochim. Acta 2005, 51, 706.

[62] R. O. Kadara, I. E. Tothill, Anal. Chim. Acta 2008, 623, 76.

[63] L. Zhu, L. Xu, B. Huang, N. Jia, L. Tan, S. Yao, Electrochim. Acta 2014, 115, 471.

[64] Y. Wei, C. Gao, F. L. Meng, H. H. Li, L. Wang, J. H. Liu, X. J. Huang, J Phys. Chem. C 2012, 116, 1034.

Received: January 6, 2016

Accepted: March 25, 2016 Published online: May 23, 2016 